\title{
Correction to: Cassava mosaic disease: a review of a threat to cassava production in Zambia
}

\author{
Patrick Chiza Chikoti $^{1} \cdot$ Rabson Mpundu Mulenga $^{1} \cdot$ Mathias Tembo $^{1} \cdot$ Peter Sseruwagi $^{2}$
}

Published online: 28 February 2019

(C) Società Italiana di Patologia Vegetale (S.I.Pa.V.) 2019

\section{Correction to: Journal of Plant Pathology \\ https://doi.org/10.1007/s42161-019-00255-0}

This correction stands to correct the erroneous corresponding author name Rabson Chiza Chikoti. The publisher and everyone involved would like readers to know that the correct name credited should be Patrick Chiza Chikoti and not the former. The original article has been corrected.

Publisher's note Springer Nature remains neutral with regard to jurisdictional claims in published maps and institutional affiliations.

The online version of the original article can be found at https://doi.org/ 10.1007/s42161-019-00255-0

Patrick Chiza Chikoti

chizachikoti@hotmail.com

1 Zambia Agriculture Research Institute, Mt. Makulu Central Research Station, P/B 7, Chilanga, Zambia

2 Mikocheni Agricultural Research Institute, P.O. Box 6226,

Dar es Salaam, Tanzania 